\title{
Long-Term Simultanity Model Of Indonesian Financial Company Value And Debt Policy
}

\author{
Rahmat Hidayat ${ }^{1}$, Rusiadi $^{*}$, Anwar Sanusi ${ }^{3}$, Rahmat Sembiring ${ }^{4}$ \\ 1,2,3,4 Universitas Pembangunan Panca Budi \\ * Corresponding author: \\ Email : rusiadi@dosen.pancabudi.ac.id
}

\begin{abstract}
Competition in financial companies makes each company increasingly improve its performance so that its goals can still be achieved. The main goal of a company is to get profits, to achieve these goals, management is required to make good planning. Likewise, management in a financial company has a goal, where the Debt Policy and Company Value will affect the company's management in achieving profits. This study aims to analyze as much as possible the effectiveness of profitability, dividend payout ratio, asset structure, Free Cash Flow, company size and sales growth and have an influence on the Debt Policy and Company Value. In this study, researchers used the OLS (Ordinary Least Square) method, the Panel Regression method and the Simultaneous / 2SLS method (Two Stage Least Square). Which aims to analyze the influence of independent variables on the dependent variables both separately and jointly and also see the influence of variables in the short and medium term.
\end{abstract}

Keywords: Debt Policy, Company Value, Profitability, Dividend Payout Ratio, Structure Asset, Free Cash Flow, Size Company and Growth Sales.

\section{INTRODUCTION}

The purpose of a company is to increase the value of the company so that it can provide prosperity for the owners or shareholders. The value of the company is a picture of the performance of the company itself. The higher the value of the company, it means that the company's performance is getting better. Of course, good company performance will be the main consideration for investors who will invest in a company. Good company performance will attract many investors and ultimately increase the company's stock price and have an impact on increasing company value. Price to Book Value is a ratio that can be used to measure company value. Financial decisions taken by financial managers are intended to increase the prosperity of company owners, this is indicated by the increase in company value (Husnan 2012). Almost all investment decisions in the capital market are based on PBV developments.

A high PBV will make investors believe in the company's prospects in the future.According to Ernawati (2016), it is stated that the higher the stock price, the higher the value of the company. High company value is the desire of shareholders, because with a high value, it shows the prosperity of shareholders is also high. Brigham and Houston (2011) say that companies with very high returns on investment use relatively small amounts of debt. This is in accordance with the pecking order theory which states that companies tend to use internal funding as much as possible before deciding to use external funding (Seftianne and Handayani, 2011). The asset structure is the wealth or economic resources owned by the company which are expected to provide benefits in the future (Kesuma, 2009). The asset structure is divided into two main parts, namely current assets which include cash, short-term investments, receivables, notes, trade receivables, inventories, advances and non-current assets which include long-term investments, fixed assets, and intangible fixed assets (Winahyuningsih, 2010). et al 2010).

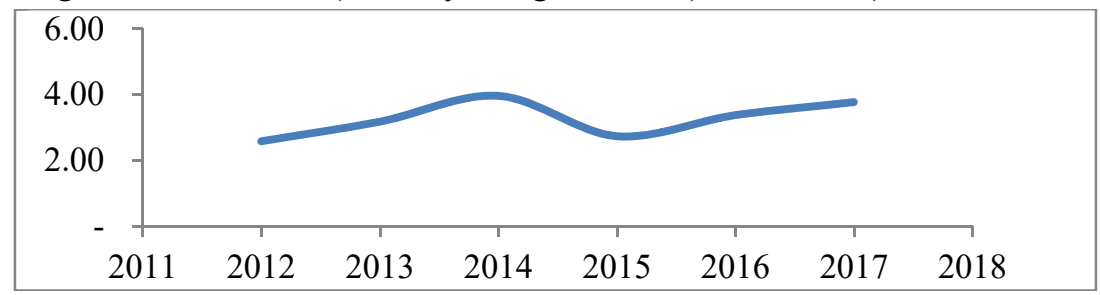

Fig 1. Graph of Debt Policy Development 
In graph 1.1, it is known that the average development (Debt to Equity Ratio) of DER in 2012-2017, where the average DER has increased and decreased every year, an increase in DER has an impact on increasing the company's debt to creditors, so when DER increases, it means that the composition of debt also increases. increased and resulted in a decrease in company profits. Because the company's profits decreased, the company was unable to pay the Dividend Payout Ratio (DPR) to shareholders. The increase in DER is due to the large amount of total debt rather than the company's capital.

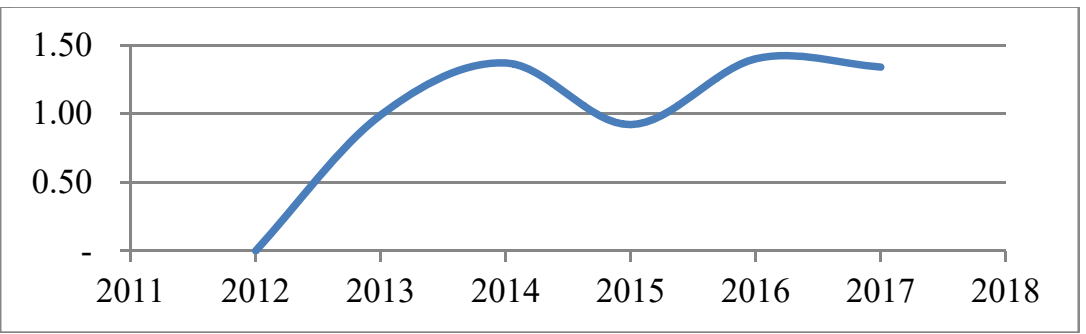

Fig 2. Graph of Company Value Development

In graph 1.2 above, it is known that the average development of company value in 2012-2017, where the average development of company value decreased in 2015 . The decline in company value has an impact on the company's net income, low company value will make the market not believe not only in performance the current company but also on the company's prospects in the future. The decline in the value of the company can reflect the value of assets owned by the company. The lower the value of the company, the company will not have a good image. Firm value is often associated with stock prices, so the lower the stock price, the lower the firm value and vice versa. Debt and Its Effect on Company Value. While this research is entitled: Simultaneous Analysis of Debt Policy and Firm Value in Financial Companies in Indonesia. The differences are:

\section{Theoritical Framework}

\section{Debt policy}

The company's debt policy is a policy taken by the management in order to obtain financing sources (funds) from third parties to finance the company's operational activities. This is closely related to the capital structure chosen by the company. Capital structure is a balance between foreign capital or debt with own capital. Company owners prefer companies to use debt at a certain level so that the expectations of company owners can be achieved. In addition, the behavior of managers and commissioners of the company can also be controlled. Debt policy company is a policy taken by the management in order to obtain funding sources from third parties to finance the company's operational activities. According to Harmono (2011:137) funding decisions by management will affect the company's research which is reflected in stock prices. Therefore, one of the tasks of financial management is to determine funding policies that can maximize share prices which are a reflection of a company's value. According to Irawan Arry (2009) said that: Debt policy is related to management decisions to increase or decrease the proportion of long-term debt and equity used in financing the company's operational activities.

The value of the company the financial objective is to maximize the value of the company. The higher the value of the company, the more prosperous the owner of the company is. According to Ernawati (2016), it is stated that the higher the stock price, the higher the value of the company. High company value is the desire of shareholders, because with a high value, it shows the prosperity of shareholders is also high. Wealth of shareholders and companies as represented by the market price of shares which is a reflection of investment decisions, financing (financing) and asset management. In fact, the use of 100 percent debt is currently difficult to find and according to the trade off theory, the higher the debt, the higher the bankruptcy burden borne by the company. The addition of debt will increase the level of risk on the company's income stream. The greater the debt, the greater the possibility that the company will not be able to pay its fixed obligations in the form of interest and principal. The risk of bankruptcy will be higher because the interest will increase higher than the tax savings. Therefore, companies must be very careful in determining their debt policy because an increase in the use of debt will reduce the value of the company. 
From some of the opinions above, it can be concluded that company value is a certain condition that has been achieved by a company as an illustration of public trust in the company after going through a process for several periods, namely since the company was founded until now. Increasing the value of the company is an achievement that is in accordance with the wishes of the owners because with the increase in the value of the company, the price of the shares owned by the company will increase and eventually will increase the welfare of the owners as well.In the opinion of experts, firm value is measured using Price To Book Value (PBV), which is a ratio that compares the price per share with the book value per share. The Price To Book Value (PBV) ratio provides an illustration of how many times we pay for a stock with the company's book value (Brigham and Houston, 2010:151).

\section{Research Methodology}

This research approach is quantitative research. According to Russiadi (2013:14): Associative/quantitative research is research that aims to determine the degree of relationship and pattern/form of influence between two or more variables, where with this research a theory will be built that serves to explain, predict and control a symptom. .

\section{2SLS (Two Stage Least Square) With Simultaneous Analysis Model}

The analytical model used is a system of simultaneous equations as follows:

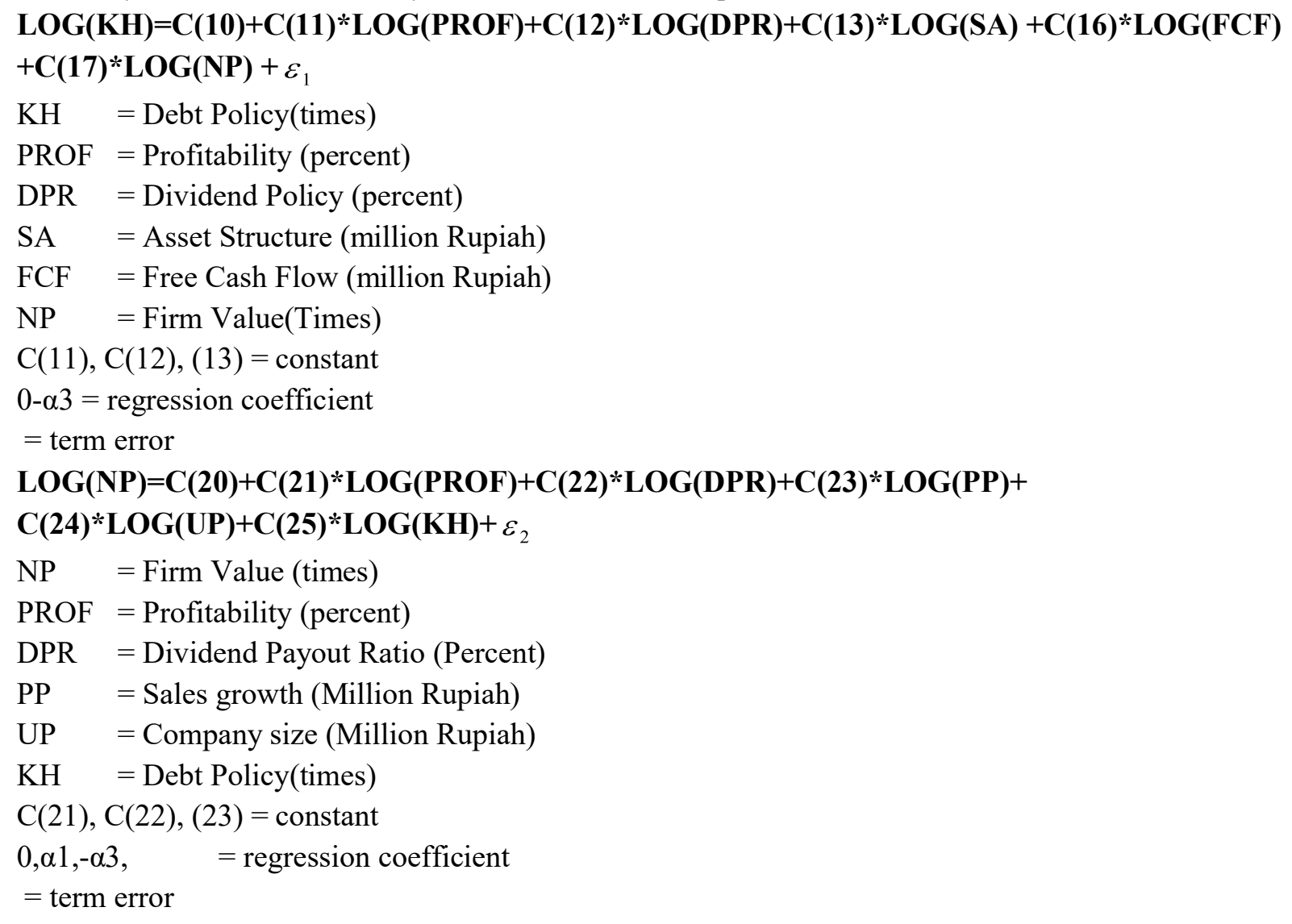

\section{Regresi Panel}

In this study using panel data, namely by using data between time and data between companies. Panel regression is used to obtain the estimation results of each individual characteristic separately.

$\mathrm{KH}_{\mathrm{it}(\mathrm{ADMF})}=\alpha+\beta 1 \mathrm{PROF}_{\mathrm{it}}+\beta 2 \mathrm{DPR}_{\mathrm{it}}+\beta 3 \mathrm{SA}_{\mathrm{it}}+\beta 4 \mathrm{FCF}_{\mathrm{it}}+\beta 5 \mathrm{PP}_{\mathrm{it}}+\beta 6 \mathrm{UP}_{\mathrm{it}}+\mathrm{e}_{1}$

$\mathrm{KH}_{\mathrm{it}(\mathrm{BBLD})}=\alpha+\beta 1 \mathrm{PROF}_{\mathrm{it}}+\beta 2 \mathrm{DPR}_{\mathrm{it}}+\beta 3 \mathrm{SA}_{\mathrm{it}}+\beta 4 \mathrm{FCF}_{\mathrm{it}}+\beta 5 \mathrm{PP}_{\mathrm{it}}+\beta 6 \mathrm{UP}_{\mathrm{it}}+\mathrm{e}_{2}$

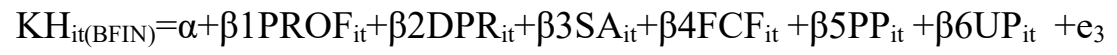

$\mathrm{KHit(BPFI)}=\alpha+\beta 1 \mathrm{PROF}_{\mathrm{it}}+\beta 2 \mathrm{DPR}_{\mathrm{it}}+\beta 3 \mathrm{SA}_{\mathrm{it}}+\beta 4 \mathrm{FCF}_{\mathrm{it}}+\beta 5 \mathrm{PP}_{\mathrm{it}}+\beta 6 \mathrm{UP}_{\mathrm{it}} \quad+\mathrm{e}_{4}$

$\mathrm{KH}_{\mathrm{it}(\mathrm{CFIN})}=\alpha+\beta 1 \mathrm{PROF}_{\mathrm{it}}+\beta 2 \mathrm{DPR}_{\mathrm{it}}+\beta 3 \mathrm{SA}_{\mathrm{it}}+\beta 4 \mathrm{FCF}_{\mathrm{it}}+\beta 5 \mathrm{PP}_{\mathrm{it}}+\beta 6 \mathrm{UP}_{\mathrm{it}}+\mathrm{e}_{5}$

$\mathrm{KH}_{\mathrm{it}(\mathrm{DEFI})}=\alpha+\beta 1 \mathrm{PROF}_{\mathrm{it}}+\beta 2 \mathrm{DPR}_{\mathrm{it}}+\beta 3 \mathrm{SA}_{\mathrm{it}}+\beta 4 \mathrm{FCF}_{\mathrm{it}}+\beta 5 \mathrm{PP}_{\mathrm{it}}+\beta 6 \mathrm{UP}_{\mathrm{it}}+\mathrm{e}_{6}$

$\mathrm{KH}_{\mathrm{it}(\mathrm{HDFA})}=\alpha+\beta 1 \mathrm{PROF}_{\mathrm{it}}+\beta 2 \mathrm{DPR}_{\mathrm{it}}+\beta 3 \mathrm{SA}_{\mathrm{it}}+\beta 4 \mathrm{FCF}_{\mathrm{it}}+\beta 5 \mathrm{PP}_{\mathrm{it}}+\beta 6 \mathrm{UP}_{\mathrm{it}}+\mathrm{e}_{7}$

$\mathrm{KH}_{\mathrm{it}(\mathrm{MFIN})}=\alpha+\beta 1 \mathrm{PROF}_{\mathrm{it}}+\beta 2 \mathrm{DPR}_{\mathrm{it}}+\beta 3 \mathrm{SA}_{\mathrm{it}}+\beta 4 \mathrm{FCF}_{\mathrm{it}}+\beta 5 \mathrm{PP}_{\mathrm{it}}+\beta 6 \mathrm{UP}_{\mathrm{it}}+\mathrm{e}_{8}$ 
$\mathrm{KH}_{\mathrm{it}(\mathrm{TIFA})}=\alpha+\beta 1 \mathrm{PROF}_{\mathrm{it}}+\beta 2 \mathrm{DPR}_{\mathrm{it}}+\beta 3 \mathrm{SA}_{\mathrm{it}}+\beta 4 \mathrm{FCF}_{\mathrm{it}}+\beta 5 \mathrm{PP}_{\mathrm{it}}+\beta 6 \mathrm{UP}_{\mathrm{it}}+\mathrm{e}_{9}$

$\mathrm{KH}_{\mathrm{it}(\mathrm{TRUS})}=\alpha+\beta 1 \mathrm{PROF}_{\mathrm{it}}+\beta 2 \mathrm{DPR}_{\mathrm{it}}+\beta 3 \mathrm{SA}_{\mathrm{it}}+\beta 4 \mathrm{FCF}_{\mathrm{it}}+\beta 5 \mathrm{PP}_{\mathrm{it}}+\beta 6 \mathrm{UP}_{\mathrm{it}}+\mathrm{e}_{10}$

$\mathrm{KH}_{\mathrm{it}(\mathrm{VRNA})}=\alpha+\beta 1 \mathrm{PROF}_{\mathrm{it}}+\beta 2 \mathrm{DPR}_{\mathrm{it}}+\beta 3 \mathrm{SA}_{\mathrm{it}}+\beta 4 \mathrm{FCF}_{\mathrm{it}}+\beta 5 \mathrm{PP}_{\mathrm{it}}+\beta 6 \mathrm{UP}_{\mathrm{it}}+\mathrm{e}_{11}$

Dimana:

\section{DISCUSION}

\section{Analisa Regresi Simultan :}

Estimates to determine the effect of variables in 2 simultaneous equations are carried out using the Two-Stage Least Square model as shown in the table below. From the table, it is known that there are 2 (two) simultaneous model equations:

- $\mathrm{LOG}(\mathrm{KH})=\mathrm{C}(10)+\mathrm{C}(11) * \mathrm{LOG}(\mathrm{PROF})+\mathrm{C}(12) * \mathrm{LOG}(\mathrm{DPR})+\mathrm{C}(13) *$

- $\quad \mathrm{LOG}(\mathrm{SA})+\mathrm{C}(14) * \mathrm{LOG}(\mathrm{FCF})+\mathrm{C}(15) * \mathrm{LOG}(\mathrm{NP})++\varepsilon_{1}$

- $\quad \mathrm{LOG}(\mathrm{NP})=\mathrm{C}(20)+\mathrm{C}(21) * \mathrm{LOG}(\mathrm{PROF})+\mathrm{C}(22) * \mathrm{LOG}(\mathrm{DPR})+\mathrm{C}(23) *$

- $\mathrm{LOG}(\mathrm{PP})+\mathrm{C}(24) * \mathrm{LOG}(\mathrm{UP})+\mathrm{C}(25) * \mathrm{LOG}(\mathrm{KH})+\varepsilon_{2}$

Tabel 1. Hasil Estimasi 2SLS

System: YCMRRNS

Estimation Method: Two-Stage Least Squares

Date: 03/20/20 Time: 16:24

Sample: 166

Included observations: 66

Total system (balanced) observations 132

\begin{tabular}{crrrr}
\hline \hline & Coefficient & Std. Error & t-Statistic & Prob. \\
\hline \hline $\mathrm{C}(10)$ & 3.074647 & 1.472164 & 2.088522 & 0.0389 \\
$\mathrm{C}(11)$ & -0.819828 & 0.374777 & -2.187507 & 0.0306 \\
$\mathrm{C}(12)$ & 0.204141 & 0.132036 & 1.546093 & 0.1247 \\
$\mathrm{C}(13)$ & -0.118074 & 0.144560 & -0.816782 & 0.4157 \\
$\mathrm{C}(14)$ & -1.121203 & 0.645078 & -1.738088 & 0.0848 \\
$\mathrm{C}(15)$ & 0.220323 & 0.773893 & 0.284694 & 0.7764 \\
$\mathrm{C}(20)$ & -0.015500 & 5.625935 & -0.002755 & 0.9978 \\
$\mathrm{C}(21)$ & 0.124125 & 0.470481 & 0.263825 & 0.7924 \\
$\mathrm{C}(22)$ & 0.072098 & 0.092960 & 0.775578 & 0.4395 \\
$\mathrm{C}(23)$ & 0.260014 & 0.279911 & 0.928917 & 0.3548 \\
$\mathrm{C}(24)$ & -0.372137 & 3.156269 & -0.117904 & 0.9063 \\
$\mathrm{C}(25)$ & -0.260505 & 0.655135 & -0.397635 & 0.6916 \\
\hline \hline Determinant residual covariance & 0.561968 & & \\
\hline \hline
\end{tabular}

Equation: $\mathrm{LOG}(\mathrm{KH})=\mathrm{C}(10)+\mathrm{C}(11) * \mathrm{LOG}(\mathrm{PROF})+\mathrm{C}(12) * \mathrm{LOG}(\mathrm{DPR})+\mathrm{C}(13)$ $*$ LOG(SA) + C (14)*LOG(FCF) + C (15)*LOG(NP)

Instruments: C PROF DPR SA FCF PP UP

Observations: 66

\begin{tabular}{llll}
\hline R-squared & 0.253663 & Mean dependent var & 0.620147 \\
Adjusted R-squared & 0.191468 & S.D. dependent var & 1.379156 \\
S.E. of regression & 1.240115 & Sum squared resid & 92.27312 \\
Durbin-Watson stat & 1.810952 & &
\end{tabular}

The first equation is the equation used to simultaneously determine the capital structure with the following equation:

$$
\begin{aligned}
& \mathrm{LOG}(\mathrm{KH})=\mathrm{C}(10)+\mathrm{C}(11) * \mathrm{LOG}(\mathrm{PROF})+\mathrm{C}(12) * \mathrm{LOG}(\mathrm{DPR})+\mathrm{C}(13) * \\
& \mathrm{LOG}(\mathrm{SA})+\mathrm{C}(14) * \mathrm{LOG}(\mathrm{FCF})+\mathrm{C}(15) * \mathrm{LOG}(\mathrm{NP})+\varepsilon_{1}
\end{aligned}
$$


Based on this equation, the results of the output eviews with the Two-Stage Least Square model are as follows:

$\mathrm{LOG}(\mathrm{KH})=3,074-0,819 * \mathrm{LOG}(\mathrm{PROF})+0,204 * \mathrm{LOG}(\mathrm{DPR})-0,118 * \mathrm{LOG}(\mathrm{SA})-1,121 * \mathrm{LOG}(\mathrm{FCF})$ $+0.220 *$ LOG(NP)

$\begin{aligned} \text { Probability }= & 0,030 \mathrm{LOG}(\mathrm{PROF}) \\ & 0,124 \mathrm{LOG}(\mathrm{DPR}) \\ & 0,415 \mathrm{LOG}(\mathrm{SA}) \\ & 0,084 \mathrm{LOG}(\mathrm{FCF}) \\ & 0,776 \mathrm{LOG}(\mathrm{NP})\end{aligned}$

The second equation is the equation used to simultaneously determine the income smoothing with the following equation:

$$
\begin{aligned}
& \mathrm{LOG}(\mathrm{NP})=\mathrm{C}(20)+\mathrm{C}(21) * \mathrm{LOG}(\mathrm{PROF})+\mathrm{C}(22) * \mathrm{LOG}(\mathrm{DPR})+\mathrm{C}(23) * \\
& \mathrm{LOG}(\mathrm{PP})+\mathrm{C}(24) * \mathrm{LOG}(\mathrm{UP})+\mathrm{C}(25) * \mathrm{LOG}(\mathrm{KH})+\varepsilon_{2}
\end{aligned}
$$

Based on this equation, the results of the output eviews with the Two-Stage Least Square model are as follows:

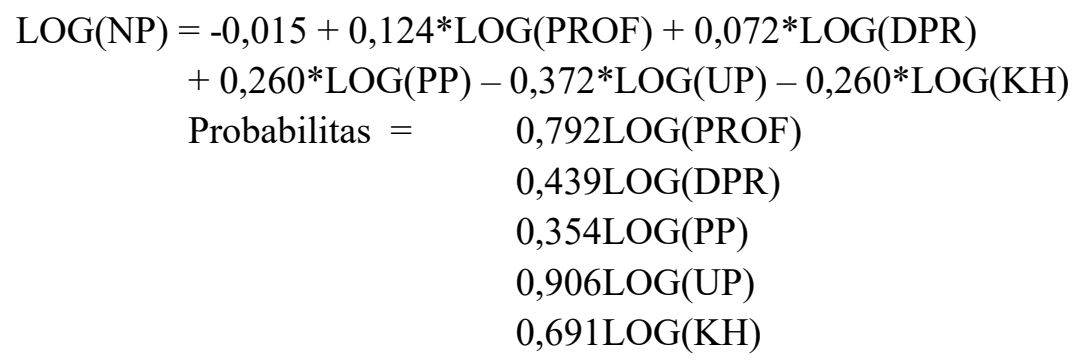

The results of this study are inconsistent with the research of Puspa Devi Maharani, Lulu Nurul Istanti and Fadia Zen (2017) Profitability has a significant positive effect on debt policy. The results of this study are in accordance with the research conducted by Jensen et al. (1992), Myers (1984), Moh'd et al. (1998), Masdupi (2005), Harjanti \& Tandelilin in Yeniarti \& Destriana (2010), and Yeniartie \& Destriana, 2010). The results of this study are inconsistent with research conducted by Hidayat (2013), Amirya \& Atmini (2008), Larasati (2011) which links dividend policy (DPR) with debt policy (DER) which results in a significant negative effect on the Dividend Payout Ratio. debt policy. The results of this study are in line with the research conducted by Tarjo \& Jogianto (2003), Soesetio (2008). Which states that the Dividend Payout Ratio has a positive but not significant effect on debt policy. The results of this study are inconsistent with research conducted by Surya and Rahayuningsih (2012) and Damayanti and Hartini (2012) that asset structure has a positive influence on debt policy. The results of this study are in accordance with research conducted by Susilawati et al. (2012), and Nugroho (2006) which stated that asset structure had a negative effect on debt policy. The results of this study are inconsistent with research conducted by Jaggi and A. Gul (1999), Damayanti (2006), Indahningrum and Handayani (2009) which states that free cash flow has a significant effect on corporate debt policy. The results of this study are in line with research conducted by Setina and Sibagariang (2013) and Syafi'i (2011) it is known that Free Cash Flow has a significant negative effect on debt policy.

The results of this study contradict the research conducted by Indrajaya and Setiadi (2011), showing that profitability has a negative effect on capital structure because if the capital structure decreases, the value of the company will also decrease. The results of this study are in line with research conducted by Soliha and Taswan (2002), showing that profitability has a positive effect on firm value. Yunita (2010), profitability has a positive effect on firm value. Mahendra (2011), shows that profitability has a positive effect on firm value. The results of this study are in line with research conducted by research conducted by Soliha and Taswan (2008) which states that firm size has a positive effect on firm value. The results of this study are inconsistent with research conducted by Kusumajaya (2011) which concluded that sales growth has a positive effect on firm value. The results of this study are not in accordance with the research conducted by Yang (2011) who found the results that debt policy had no significant effect on firm value. 
Panel Regression Interpretation The data analysis used is by combining time series data and inter-company data (cross section data). The combination of these two types of data becomes pooling data. The author tested the research data with estimation methods, namely pooled least squares with a common intercept and generalized least squares with random effects models. From the results of calculations using the pooled least squares estimation method with a common intercept, using eviews software, the following results are obtained:

Tabel 2. Hasil Estimasi Regresi Panel

Dependent Variable: KH?

Method: Pooled Least Squares

Date: 03/12/20 Time: 00:46

Sample: 20122017

Included observations: 6

Cross-sections included: 11

Total pool (balanced) observations: 66

\begin{tabular}{crrrr}
\hline \hline Variable & Coefficient & Std. Error & t-Statistic & Prob. \\
\hline \hline PROF? & -0.298490 & 0.102716 & -2.905979 & 0.0051 \\
DPR? & -0.002590 & 0.006573 & -0.394014 & 0.6950 \\
SA? & 1.851911 & 0.966612 & 1.915878 & 0.0601 \\
FCF? & -0.073689 & 0.092996 & -0.792382 & 0.4313 \\
PP? & 0.021854 & 0.007114 & 3.071857 & 0.0032 \\
UP? & 0.648720 & 0.142155 & 4.563480 & 0.0000 \\
\hline \hline R-squared & 0.294517 & Mean dependent var & 3.023333 \\
Adjusted R-squared & 0.235726 & S.D. dependent var & 2.175316 \\
S.E. of regression & 1.901721 & Akaike info criterion & 4.209903 \\
Sum squared resid & 216.9925 & Schwarz criterion & 4.408963 \\
Log likelihood & -132.9268 & Hannan-Quinn criter. & 4.288561 \\
Durbin-Watson stat & 0.598438 & & & \\
\hline \hline
\end{tabular}

Substituted Coefficients:

KH_ADMF $=-0.298490 *$ PROF_ADMF $-0.002590 *$ DPR_ADMF $+1.851911 *$ SA_ADMF $0.073689 * \mathrm{FCF} \_\mathrm{ADMF}+0.021854 * \mathrm{PP} \_\mathrm{ADMF}-0.648720 * \mathrm{UP} \_\mathrm{ADMF}$

KH_BBLD $=-0.298490 *$ PROF_BBLD $-0.002590 *$ DPR_BBLD $+1.851911 *$ SA_BBLD $0.073689 *$ FCF_BBLD $+0.021854 *$ PP_BBLD $-0.648720 *$ UP_BBLD

KH_BFIN $=-0.298490 *$ PROF_BFIN $-0.002590 *$ DPR_BFIN $+1.851911 *$ SA_BFIN $-0.073689 *$ FCF_ $\mathrm{BFIN}+0.021854 * \mathrm{PP} \_\mathrm{BFIN}-0.648720 * \mathrm{UP}_{-} \mathrm{BFIN}$

KH_BPFI $=-0.298490 *$ PROF_BPFI $-0.002590 *$ DPR_BPFI $+1.851911 *$ SA_BPFI $-0.073689 *$ FCF_ BPFI + 0.021854*PP_BPFI $-0.648720 *$ UP_BPFI

KH_CFIN $=-0.298490 *$ PROF_CFIN $-0.002590 *$ DPR_CFIN $+1.851911 *$ SA_CFIN $-0.073689 * F C F \_$ CFIN $+0.021854 *$ PP_CFIN $-0.648720 *$ UP_CFIN

KH_DEFI $=-0.298490 *$ PROF_DEFI $-0.002590 *$ DPR_DEFI $+1.851911 *$ SA_DEFI $-0.073689 * F C F \_$ DEFI $+0.021854 *$ PP_DEFI $-0.648720 *$ UP_DEFI

KH_HDFA $=-0.298490 *$ PROF_HDFA $-0.002590 *$ DPR_HDFA $+1.851911 *$ SA_HDFA $0.073689 *$ FCF_HDFA $+0.021854 *$ PP_HDFA $-0.648720^{*}$ *UP_HDFA

KH_MFIN $=-0.298490 *$ PROF_MFIN $-0.002590 *$ DPR_MFIN $+1.851911 *$ SA_MFIN $-0.073689 *$ FCF $\mathrm{MFIN}+0.021854 * \mathrm{PP} \_$MFIN $-0.648720 * \mathrm{UP}_{-}$MFIN

KH_TIFA $=-0.298490 *$ PROF_TIFA $-0.002590 *$ DPR_TIFA $+1.851911 *$ SA_TIFA $-0.073689 *$ FCF TIFA $+0.021854 *$ PP_TIFA $-0.648720 *$ UP_TIFA

KH_TRUS $=-0.298490 *$ PROF_TRUS $-0.002590 *$ DPR_TRUS $+1.851911 *$ SA_ TRUS $-0.073689 * \mathrm{FCF}$ TRUS $+0.021854 *$ PP_TRUS $-0.648720 *$ UP_TRUS 


\section{KH_VRNA $=-0.298490 *$ PROF_VRNA $-0.002590 *$ DPR_VRNA $+1.851911 *$ SA_VRNA - $0.073689 *$ FCF_VRNA + 0.021854*PP_VRNA $-0.648720 *$ UP_VRNA}

Based on the estimation results using pooled least squares with a common intercept, it gives the estimation results, R2 resulting from the estimation of the equation in this study is $29.45 \%$ during the observation period. It can be concluded that with the pooled least squares analysis method with a common intercept, the variation of the independent variable in this study is only able to explain $29.45 \%$ of the variation in the dependent variable, namely Debt Policy, while the remaining $70.55 \%$ is explained by other variables that are not included. in the research model. According to the estimation results of the Debt Policy equation using the Fixed Effect on Generalized Least Square, the R2 of the equation estimation result is $74.9 \%$. The estimation results can be interpreted that the estimation model of the GLS equation can explain the variation of the equation of the independent variable on the dependent variable by $74.9 \%$. While the remaining $25.1 \%$ Debt Policy is explained by other variables that are not included in this research model.

\section{CONCLUTION}

Based on the interpretation of 2SLS (Two Stage Least Square) that the variables of Dividend Payout Ratio, Asset Structure and firm value affect debt policy, which is positive and not significant. Profitability variable, Free Cash Flow has a significant effect on Debt Policy. Profitability variables, Dividend Payout Ratio, sales growth, company size and debt policy have no significant effect on firm value. Based on the results of the study, it is known that the pooled least square research model with a common intercept, gives an estimate, R2 resulting from the estimation of the equation in this study, which is $29.45 \%$ during the observation period. The results of the estimation of the Debt Policy equation using the Fixed Effect on Generalized Least Square, obtained R2 from the estimation of the equation is $74.9 \%$. The results of the estimation of the Capital Structure equation using Random Effects on Generalized Least Square, obtained R2 the result of the estimated equation is $13.1 \%$.

\section{REFERENCES}

[1] Asril. (2013). Pasar Modal (Penawaran Umum dan Permasalahannya), Citra Aditya Bakti, Bandung.

[2] Astuti, Dewi. (2013). Manajemen Keuangan Perusahaan, Ghalia Indonesia, Jakarta.

[3] Husnan, Suad, (2014). Manajemen Keuangan (Teori dan Penerapan Keputusan Jangka Panjang), BPFE, Yogyakarta.

[4] Barton, Sidney L., Ned C. Hill dan Sirinivasan Sundaran, (2013). An Empirical Test of Stakeholder Theory Predictions of Capital Structure. Journal of the Financial Management Association, Spring.

[5] Brigham, Eugene F dan Joel F Houston, (2015). Manajemen Keuangan Buku 2. Edisi Delapan, Gelora Aksara Pratama, Jakarta.

[6] Erlina, (2013). Metodologi Penelitian Bisnis : untuk Akuntansi dan Manajemen, Edisi Revisi, USU Press, Medan.

[7] Harjito, Dwipraptono Agus.(2007).” Analisis Hubungan antara Kepemilikan Insider, Leverage Perusahaan dan Kebijakan Dividen”. Telaah Bisnis 8 (1), PPPM Sekolah Tinggi Ilmu Manajemen, YKPN, Yogyakarta, Juli, 2007

[8] Wahyudi, Untung dan Hartini Prasetyaning Prameswari. (2006). Implikasi Struktur Kepemilikan terhadap Nilai Perusahaan: Dengan Kaputusan Keuangan sebagai Variabel Intervening. Makalah Simposium Nasional Akuntansi (SNA) 9 Padang

[9] Kesuma, Ali, (2013). Analisis Faktor yang Mempengaruhi Struktur Modal Serta Pengaruhnya Terhadap Harga Saham Perusahaan Real Estate yang Go Public di Bursa Efek Indonesia. Jurnal Manajemen dan Kewirausahaan. Vol.11.No.1. h:38-45.

[10] Wijaya, Putu Andre Sucita. (2014). Pengaruh Profitabilitas, Struktur Aset, Dan Pertumbuhan Penjualan Terhadap Struktur Modal Serta Harga Saham.

[11] Halim, Abdul. (2015). Manajemen Keuangan Bisnis, Ghalia Indonesia, Jakarta.

[12] Hatta, Atika J, (2013). Faktor-faktor yang Mempengaruhi Kebijakan Dividen Investifasi Pengaruh Teori Stakeholder Pertumbuhan Penjualan, JAAL Vol.6.No.2.Desember.

[13] Jensen, M.C dan W.H Meckling, (2014). Theory of the Firm : Manajerial Behavior Agency Cost and ownership Structure. Journal of Financial Economics. Vol.3, October, pp 305-360. 
[14] Jogiyanto, (2014). Teori Portofolio dan Analisis Investasi, BPFE, Yogyakarta.

[15] Joni dan Lina, (2015). Faktor-faktor yang Mempengaruhi Struktur Modal. Stie Trisakti. Jurnal Bisnis danAkuntansi Vol.12 No.2 Agustus.

[16] Lubis, Ade, Fatwa. (2013). Pasar Modal, Lembaga Penerbit Fakultas Ekonomi Universitas Indonesia, Jakarta.

[17] Mahapsari, Nunky R. dan Taman, Abdullah, (2013). Analisis Profitabilitas, Struktur Aset dan Pertumbuhan Penjualatan Terhadap Harga Saham Dengan Struktur Modal Sebagai Variabel Intervening Pada Perusahaan Manufaktur Yang Terdaftar Di Bursa Efek Indonesia. Jurnal Nominal. Vol.1.No.2.

[18] Mardiansyah, Tommy. (2015). Pengaruh Profitabilitas dan Operating Leverage Terhadap Struktur Modal Pada Perusahaan Makanan Dan Minuman Yang Terdaftar Di Bursa Efek Indonesia (BEI) Tahun 2008-2011. Volume 6, Nomor 10. Universitas Negeri Padang.

[19] Martono dan Agus Harjito, (2013). Manajemen Keuangan, EKONESIA, Yogyakarta.

[20] Novitasari, Bunga. (2015). Pengaruh Profitabilitas, Pertumbuhan Penjualan, Dan Kebijakan Dividen Terhadap Harga Saham. Sekolah Tinggi Ilmu Ekonomi Indonesia (STIESIA) Surabaya.

[21] Pattinasarani, Stefany Christianingsih. (2016). Pengaruh Profitabilitas, Pertumbuhan Penjualan, Ukuran Perusahaan Dan Kepemilikan Manajerial Terhadap Struktur Modal. Jurnal Ilmu dan Riset Akuntansi : Volume 5, Nomor 6, Juni 2016. Sekolah Tinggi Ilmu Ekonomi Indonesia (STIESIA) Surabaya.

[22] Sartono, R. Agus, (2014). Manajemen Keuangan Teori dan Aplikasi, Edisi Keempat, Cetakan Pertama, BPFE, Yogyakarta.

[23] Sudaryono, (2011). Aplikasi Analisis (Path Analysis) Berdasarkan Urutan Penempatan Variabel Dalam Penelitian. Jurnal Pendidikan dan Kebudayaan, Vol. 17, Nomor 4, Juli 2011.

[24] Thausyah, Nudzunul Fiara. (2015). Pengaruh Pertumbuhan Penjualan, Struktur Aktiva Dan Profitabilitas Terhadap Struktur Modal.

[25] Sugiyono, (2014). Metode Penelitian Pendidikan (Pendekatan Kuantitatif, Kualitatif dan R\&D). Penerbit Alfabeta.Bandung.

[26] Rusiadi, et al (2014), Metode Penelitian Manajemen, Akuntansi dan Ekonomi Pembangunan, Konsep, Kasus dan Aplikasi SPSS, Eviews, Amos dan Lisrel. Cetakan Pertama. Medan : USU Press. 